\title{
WORKING CONTEXT IN A HEMODIALYSIS SERVICE: EVALUATION OF NURSING STAFF
}

\author{
Francine Cassol Prestes ${ }^{1}$, Carmem Lúcia Colomé Beck², Tânia Solange Bosi de Souza Magnago ${ }^{3}$, Rosangela \\ Marion da Silva ${ }^{4}$, Juliana Petri Tavares ${ }^{5}$
}

\footnotetext{
${ }^{1}$ Doctoral student. Nurse technical-administrative in education, Departamento de Enfermagem da Universidade Federal de Santa Maria (UFSM). Santa Maria, Rio Grande do Sul, Brazil. E-mail: francinecassol@gmail.com

${ }^{2}$ Ph.D. in Nursing. Associate Curso de Enfermagem, UFSM. Santa Maria, Rio Grande do Sul, Brazil. E-mail: carmembeck@ gmail.com

${ }^{3}$ Ph.D. in Nursing. Adjunct Professor Curso de Enfermagem, UFSM. Santa Maria, Rio Grande do Sul, Brazil. E-mail: tmagnago@ terra.com.br

${ }^{4}$ Ph.D. in Science. Adjunct Professor, Curso de Enfermagem. UFSM. Santa Maria, Rio Grande do Sul, Brazil. E-mail: cucasma@ terra.com.br

${ }^{5}$ Ph.D. in Nursing. Professor, Centro Universitário Metodista IPA.Porto Alegre, Rio Grande do Sul, Brazil. E-mail: jupetritavares@ gmail.com
}

\begin{abstract}
The aim of this study was to assess the working context and relate it to the physical suffering in nursing staff in hemodialysis services in southern Brazil. Quantitative study, with 46 staff, conducted in 2011. Inclusion criteria: working in nursing for at least six months. The staff who were absent from work during data collection were excluded from the study. A self-completed form requiring socio-demographic and work data and the Work Context Assessment Scale were used. A descriptive and bivariate analysis was performed, with a confidence level of $95 \%$, using Epi-info ${ }^{\circledR}$ and Predictive Analytics Software. Work organization was considered critical, socio-professional relationships and work conditions were evaluated as satisfactory. The least satisfied staff concerning their remuneration, and those who suffered a work accident evaluated the socio-professional relationship as critical. The research context is not totally propitious, and interventions are needed in order to avoid harm to staff member health.
\end{abstract}

DESCRIPTORS: Nursing. Occupational health. Renal dyalisis. Working conditions.

\section{CONTEXTO DE TRABALHO EM UM SERVIÇO DE HEMODIÁLISE: AVALIAÇÃO DOS TRABALHADORES DE ENFERMAGEM}

\begin{abstract}
RESUMO: Objetivou-se avaliar o contexto de trabalho e relacioná-lo com o sofrimento psíquico em trabalhadores de enfermagem de um serviço de hemodiálise do Sul do Brasil. Pesquisa quantitativa, com 46 trabalhadores em 2011. Os critérios de inclusão foram: ser trabalhador de enfermagem do serviço há pelo menos seis meses. Foram excluídos os trabalhadores afastados no período de coleta dos dados. Utilizou-se um formulário auto-preenchível com dados sociodemográficos, laborais e a Escala de Avaliação do Contexto de Trabalho. Realizou-se a análise descritiva e bivariada com níveis de confiança de $95 \%$, utilizando-se os programas Epi-info ${ }^{\circledR}$ e Predictive Analytics Software. A organização do trabalho foi considerada crítica, as relações socioprofissionais e condições de trabalho satisfatórias. Os trabalhadores menos satisfeitos com a remuneração e os que sofreram acidente de trabalho avaliaram criticamente as relações socioprofissionais. O contexto pesquisado não é totalmente favorável, existindo a necessidade de intervenções, a fim evitar danos à saúde dos trabalhadores.
\end{abstract}

DESCRITORES: Enfermagem. Saúde do trabalhador. Diálise renal. Condições de trabalho.

\section{CONTEXTO DE TRABAJO EN UN SERVICIO DE HEMODIÁLISIS: EVALUACIÓN DE LOS TRABAJADORES DE ENFERMERÍA}

\begin{abstract}
RESUMEN: El estudio tuvo como objetivo evaluar el contexto de trabajo y relacionarlo con sufrimiento psíquico entre el personal de enfermería en un servicio de hemodiálisis del sur de Brasil. Estudio cuantitativo realizado en 2011, con 46 trabajadores. Criterios de inclusión: trabajar en la enfermería al menos 6 meses. Fueron excluidos los trabajadores apartados en el periodo de la colecta de datos. Utilizaron un formulario auto-rellenable con datos sociodemográficos, laborales y la Escala de Evaluación del Contexto de Trabajo. Se realizó el análisis descriptivo y bivariado con niveles de confianza del 95\%, utilizando los programas Epi-info® y Predictive Analytics Software. La organización del trabajo fue considerada crítica, las relaciones socio profesionales y condiciones de trabajo satisfactorias. Los trabajadores menos satisfechos con el sueldo y los que sufrieron accidente de trabajo evaluaron las relaciones socios profesionales. El contexto investigado no es favorable habiendo necesidad de intervenciones con la finalidad de evitar a la salud de los trabajadores. DESCRIPTORES: Enfermería. Salud laboral. Diálisis renal. Condiciones de trabajo.
\end{abstract}




\section{INTRODUCTION}

The centrality of work in an individual's life can be seen in the construction of his identity, in self-realization, mental health, and even somatic health. From this perspective, work activity can promote health, having a pivotal role, or it can contribute to its destabilization, leading the subject to imbalance, which confirms the assumption that work is never neutral for the staff member's health. ${ }^{1}$

Although the binomial "work and health" has been studied in recent decades, there is difficulty in establishing a causal link between work and illness, even with the constant forms of capital accumulation and work aspects. From the same perspective, there is an increase in work-related disease, ${ }^{2}$ especially in some areas of activity, such as nursing.

This occupation is identified as a profession with high risk of staff illness, as the occupational hazards are not limited to ergonomics, but biological, chemical, physical and occupational accidents, as well. New issues, such as the organization of work processes to meet the demands of health services, are added to the already known risks. ${ }^{3}$

In this sense, the relationship between occupational exposure and the onset of diseases has been known since antiquity. ${ }^{4}$ Although the nursing staff care about looking out for others, they often forget to take care of themselves and of the space where they work, which is reflected in illness, due to conditions of exposure and an unfavorable environment for the performance of their activities. ${ }^{5}$

As for the necessity for the occupational health field to adopt different approaches to contemplate the complexities of the current workplace settings, which are listed on new management forms and involve risks and costs for subjects, ${ }^{6}$ this research evaluated the nursing work environment in a hemodialysis service, from the perspective of the psychodynamics of work, which constitutes an approach that studies the dynamic relationships between the organization of work and the staff's subjective processes. ${ }^{7}$

The work context is characterized by representations related to three factors: work organization, working conditions and social and professional relationships. The organization is defined by the division of labor and the content of tasks, standards, controls and work pace. The socioprofessional relationships represent the manner of work management, professional communication and interaction. Working conditions are defined as the quality of the physical environment of the workplace, equipment and materials available for the performance of work activities. ${ }^{8}$

The option to evaluate the work context in a hemodialysis service is justified because this is a nursing practice area with different requirements, not only the need to monitor highly technical and complex therapy, but also the chronic illness of patients who undergo treatment as a condition inherent for maintenance of life. Also, despite the growing number of dialysis patients in Brazil, nephrology nursing remains a poorly researched area of activity in Brazilian studies, from the perspective of staff health.

The present study aimed to evaluate the work context and relate it to mental suffering among nursing staff of a hemodialysis center in southern Brazil.

\section{METHOD}

This was a quantitative, cross-sectional study conducted in a dialysis service located in southern Brazil. This service was an intra-hospital private institution, contracted by the Unified Health System (SUS), which provides treatment in two units (main unit and one branch unit) to about 300 patients receiving a regular hemodialysis program.

The population was composed of 51 nursing staff. The inclusion criteria were: being a member of the nursing staff of the dialysis service for at least six months. Exclusion criteria were: being on vacation or any other type of absence from work during the data collection period, which occurred in March and April of 2011.

Staff who met the inclusion criteria were individually addressed in the workplace, informed about the research objectives and invited to participate. The survey instrument was provided by the researcher to the staff in an encrypted envelope, guiding him on how to complete the form. Participants could choose to respond or not to the research in the workplace. In cases in which staff did not return the instruments, a second contact was made, and a new date for delivery was established. Staff who did not return the instrument after the second contact were considered as a loss.

The survey form contained information regarding demographic data, employment, and the Work Context Assessment scale (WCAS-EACT). This is one of four scales composing the Inventory of Work and Risks of Illness (IWRI-ITRA), an 
instrument validated in Brazil ${ }^{8}$ self-report, which evaluates some dimensions of the interrelationship between work and risk of disease. ${ }^{8}$ The other three scales that comprise the ITRA are: Human Cost at Work Scale, Indicators of Pleasure and Suffering at Work Scale, and the Work-related Damage Assessment Scale. ${ }^{8}$

The WCAS-EACT, used in this study, consists of three factors: the organization of work, social and professional relationships, and working conditions. It is a five point scale where: 1 - never; 2- rarely, 3- sometimes, 4 - frequently 5 - always. ${ }^{8}$

The Epi-Info ${ }^{\circledR}$ program, version 6.04, was used for the data record,with independent duplicate typing. After correction of errors and inconsistencies, the analysis was performed in the Predictive Analytics Software (PASW) Statistic ${ }^{\circledR}$ program, version 18.0 for Windows. A descriptive analysis was conducted; qualitative variables were described by absolute and relative frequency, and quantitative by measures of central tendency and dispersion (mean and standard deviation).

For evaluating the work context, a clustering of items that comprised each factor was conducted and a descriptive analysis was performed, considering a standard deviation from the midpoint. As recommended by the authors of the WCAS-EACT, the risk of illness was assessed as follows: ${ }^{8}$

- Above 3.7 = negative, severe assessment

- Between 2.3 and 3.69 = moderate, critical assessment.

- Below 2.29 = positive, satisfactory assessment

Thereafter, bivariate analyses were performed. For associations between the variables of the WCAS-EACT and the sociodemographic and labor variables (categorical), the chi-square test or Fisher exact test were used, with a confidence interval of $95 \%(\mathrm{p}<0.05)$. The reliability evaluation of factors was obtained by estimating the internal consistency using the Cronbach's alpha coefficient.

This study followed the Ethical Guidelines for Research Involving Human Beings, established in Resolution no. 466/12 of the National Health Council, and obtained a favorable opinion for its conduct by the Ethics and Research Committee of the Universidade Federal de Santa Maria (CEP / UFSM), with the presentation of the Certificate of Ethical Assessment, number 0364.0.243.000 - 10, 03/03/2011. Each participant received, read and signed the Terms of Free and Informed Consent, in duplicate.

\section{RESULTS}

Of 51 nursing staff, 46 participated in the study. Three staff were excluded; one had less than six months of experience in providing care, and two were removed for health treatment during the data collection period. The losses $(4.1 \%, \mathrm{n}=2)$ correspond to instruments that were not returned completed.

Among the respondents, there was a predominance of females $(80.4 \%, \mathrm{n}=37)$, mean age of 39.9 years $(\mathrm{SD}=10.02)$, nursing technicians $(67.4 \%$, $\mathrm{n}=31$ ), with a mean time of experience in the area of 10.28 years $(\mathrm{SD}=6.64)$, and without another job $(73.9 \%, \mathrm{n}=34)$. The largest part of the staff members $(56.5 \%, \mathrm{n}=26)$ showed satisfaction with the current remuneration of $75 \%$; did not have work accidents $(82.6 \% ; n=38)$, and had no absence from work for health reasons in the last year $(67.4 \% ; n=31)$.

Table 1 below shows the means, the illness risk classification, and Cronbach's alpha factors of the Work Context Assessment Scale, according to the evaluation of hemodialysis area nursing staff.

Table 1 - Descriptive statistics, illness risk classification, and Cronbach's alpha factors of Work Context Assessment Scale Assessment Scale (WCAS-EACT). Santa Maria-RS, Brazil, 2011 (n=46)

\begin{tabular}{lcccc}
\hline WCAS-EACT factor & Mean & Standard deviation & Classification & Cronbach's alpha \\
\hline Work organization & 2.91 & 0.40 & Critical & 0.63 \\
Socio-professional relationships & 2.28 & 0.52 & Satisfatory & 0.70 \\
Work conditions & 1.99 & 0.59 & Satisfatory & 0.75 \\
\hline
\end{tabular}

In evaluating the work context, work organization was considered critical $(\mu=2.91, \mathrm{SD}=0.40)$, suggesting a moderate risk of illness for nursing staff in the studied context. In this factor, the item: "tasks are repetitive" $(\mu=4.41, \mathrm{SD}=0.409)$ showed a "severe" risk rating, receiving the worst evaluation.

The socio-professional relationships $(\mu=2.28$, $\mathrm{SD}=0.52)$ and working conditions $(\mu=1.99$, 
$\mathrm{SD}=0.59)$ received satisfactory evaluations. Despite this assessment, of the ten items that comprised the factor, social and professional relationships, five were rated as critical, especially "lack of integration in the work environment" $(\mu=2.96$, $\mathrm{SD}=0.759$ ) and "communication among employees is unsatisfactory" $(\mu=2.80, \mathrm{SD}=0.778)$, which obtained the highest means. Likewise, working conditions had a critical evaluation of two items: "there is a lot of noise in the work environment" $(\mu=3.43, S D=0.26)$, and "working conditions pose risks to the people safety" $(\mu=2.70, S D=1.57)$.

The work organization factor showed a Cronbach's alpha equal to 0.63 , and items were removed, however, there was no significant change in the value of alpha, so it remained during the factor analysis. Other factors had satisfactory values, as shown in Table 1.

Table 2 shows the summary of the highest percentages in the factors and their evaluations of the work context, considering the socio-demographic variables.

Table 2 - Distribution of the highest percentages, according to the classification of the factors of the Work Context Assessment Scale (WCAS-EACT), considering the socio-demographic variables. Santa Maria-RS, Brazil, $2011(n=46)$

\begin{tabular}{|c|c|c|c|}
\hline Variables & Work organization & Socio-professional relationships & Work conditions \\
\hline \multicolumn{4}{|l|}{ Sex } \\
\hline Male & 77.8\% (n=7) Critical & $55.6 \%(n=5)$ Critical & $66.7 \%(n=6)$ Satisfactory \\
\hline Female & $81.3 \%(n=7)$ Critical & $51.4 \%(n=19)$ Critical & $73 \%(n=27)$ Satisfactory \\
\hline \multicolumn{4}{|c|}{ Age group (years) } \\
\hline $25-32$ & 71.4\% (n=10) Critical & $57.1 \%(n=8)$ Satisfactory & $64.3 \%(n=9)$ Satisfactory \\
\hline $33-41$ & $81.3 \%(n=13)$ Critical & $62.5 \%(n=10)$ Critical & $75 \%(n=12)$ Satisfactory \\
\hline $42-66$ & 93.8\% $(n=15)$ Critical & $53.6 \%(n=9)$ Critical & $75 \%(n=12)$ Satisfactory \\
\hline \multicolumn{4}{|c|}{ Marital status } \\
\hline Single & $75 \%(n=12)$ Critical & $56.3 \%(n=9)$ Critical & $62.5 \%(n=10)$ Satisfactory \\
\hline Married & $86.7 \%(n=26)$ Critical & $50 \%(n=15)$ Critical & $76.7 \%(n=23)$ Satisfactory \\
\hline \multicolumn{4}{|c|}{ Children under 6 years } \\
\hline Yes & 69.2\% (n=9) Critical & $61.5 \%(n=8)$ Satisfactory & $84.6 \%(n=11)$ Satisfactory \\
\hline No & $87.9 \%(n=29)$ Critical & $60.6 \%(n=20)$ Critical & $66.7 \%(n=22)$ Satisfactory \\
\hline \multicolumn{4}{|c|}{ Satisfaction with remuneration } \\
\hline $25 \%$ & $75 \%(n=3)$ Critical & $50 \%(n=2)$ Critical & $75 \%(n=3)$ Critical \\
\hline $50 \%$ & 91.7\% (n=11) Critical & $50 \%(n=6)$ Satisfactory/Critical & $66.7 \%(n=8)$ Satisfactory \\
\hline $75 \%$ & $76.9 \%(n=20)$ Critical & $61.5 \%(n=16)$ Critical & $80.8 \%(n=21)$ Satisfactory \\
\hline $100 \%$ & $100 \%(n=4)$ Critical & $100 \%(n=4)$ Satisfactory & $75 \%(n=3)$ Satisfactory \\
\hline
\end{tabular}

A homogeneous evaluation of the work environment was identified in the hemodialysis area, considering the variables of sex and marital status ( $p>0.05)$. Staff members aged between 25 and 32, and those with children under six years of age, were less critical when assessing the socio-economic relationships, compared to other groups ( $p>0.05)$. Regarding the satisfaction with current compensation, the least satisfied staffs evaluated more negatively the socio-economic relations $(p=0.044)$.

Table 3 presents a summary of the highest percentages among the factors, and their evaluations of the work context, considering the labor variables.
A relatively homogeneous assessment of all variable factors was identified for work organization and work conditions ( $p>0.05)$. In the factor, socio-professional relationships, nurses and staff who worked 1-5 years in the service, who had another job, those who were absenct from work for health treatment in the last year, had more positive evaluations of work relationships, compared to the other groups ( $\mathrm{p}>0.05)$.

Still in this same factor, staff who had a work accident showed a more critical evaluation in socio-professional relationships, compared to those who did not have accidents in the last year $(p=0.032)$. 
Table 3 - Distribution of the highest percentages, according to the classification of the factors of Work Context Assessment Scale (WCAS-EACT), considering the labor variables. Santa Maria-RS, Brazil $2011(n=46)$

\begin{tabular}{lccc}
\hline Variables & Work organization & Socio-professional relationships & Work conditions \\
\hline Professional category & & & \\
Nurse & $75 \%(\mathrm{n}=3)$ Critical & $75 \%(\mathrm{n}=3)$ Satisfactory & $100 \%(\mathrm{n}=4)$ Satisfactory \\
Nursing technician & $80.64 \%(\mathrm{n}=25)$ Critical & $48.4 \%(\mathrm{n}=15)$ Satisfactory & $71 \%(\mathrm{n}=22)$ Satisfactory \\
Nursing assistant & $90.9 \%(\mathrm{n}=10)$ Critical & $72.7 \%(\mathrm{n}=8)$ Critical & $63.3 \%(\mathrm{n}=7)$ Satisfactory \\
Time of working (years) & & & \\
$1-5$ & $75 \%(\mathrm{n}=9)$ Critical & $66.7 \%(\mathrm{n}=8)$ Satisfactory & $66.7 \%(\mathrm{n}=8)$ Satisfactory \\
$6-12$ & $83.3 \%(\mathrm{n}=15)$ Critical & $61.1 \%(\mathrm{n}=11)$ Critical & $72,2 \%(\mathrm{n}=13)$ Satisfactory \\
$13-25$ & $87,5 \%(\mathrm{n}=14)$ Critical & $56.3 \%(\mathrm{n}=9)$ Critical & $75 \%(\mathrm{n}=12)$ Satisfactory \\
Other job & & & \\
Yes & $91.7 \%(\mathrm{n}=11)$ Critical & $58.3 \%(\mathrm{n}=7)$ Satisfactory & $75 \%(\mathrm{n}=9)$ Satisfactory \\
No & $79.4 \%(\mathrm{n}=27)$ Critical & $58.8 \%(\mathrm{n}=20)$ Critical & $70.6 \%(\mathrm{n}=24)$ Satisfactory \\
Work accidents & & & \\
Yes & $87.5 \%(\mathrm{n}=7)$ Critical & $75 \%(\mathrm{n}=6)$ Critical & $75 \%(\mathrm{n}=60)$ Satisfactory \\
No & $81.6 \%(\mathrm{n}=31)$ Critical & $52.6 \%(\mathrm{n}=20)$ Satisfactory & $71.1 \%(\mathrm{n}=27)$ Satisfactory \\
Absence from work & & & \\
Yes & $83.9 \%(\mathrm{n}=26)$ Critical & $51.6 \%(\mathrm{n}=16)$ Satisfactory & $60 \%(\mathrm{n}=9)$ Critical \\
No & $80 \%(\mathrm{n}=12)$ Critical & $77.4 \%(\mathrm{n}=24)$ Satisfactory & $60 \%(\mathrm{n}=9)$ Satisfactory \\
\hline
\end{tabular}

\section{DISCUSSION}

Work organization includes the work division, tasks content, power relationships involving a hierarchical system, command arrangements, and responsibility issues. ${ }^{8}$ These elements dynamically interrelate and permeate the processes of staff subjectivity, which directly affect their health.

Nursing work organization in the studied service was considered critical, with positive results, when compared with a study ${ }^{5}$ on the work organization of intensive care nurses who showed serious risk of illness with this factor. However, this mean value indicates an "extreme situation", production of mental cost and suffering at work, which requires measures in the short and medium term. ${ }^{8}$

Repetitive task, assessed as critical in the nursing work organization in the hemodialysis service, deserves special attention, considering that it can cause feelings of boredom, anger, tiredness and fatigue for the staff, when confronted by the pressure for productivity and time for the execution of activities. ${ }^{9}$

Research on the dynamics of nursing work in a hemodialysis service mentions characteristics such as the completion of the work in shifts, the need to perform activities in a given space of time, performing the same procedure every day and, with that, the repetitive tasks, added to the fact of seeing the same patients. In addition to repetition, the authors also claim that there is pressure for getting things right, especially in terms of not compromising the performance of the hemodialysis procedure, or putting the patient in situations of risk. ${ }^{10}$

Working relationships are constituted in all human bonds originating from work organization, such as relationships within the hierarchy, the managers, supervisors and other staff. ${ }^{8}$ Individual differences influence interpersonal relationships and interfere with the groups dynamics integrated into organizations, which can reverberate in work conflicts. ${ }^{11}$ In addition to these aspects, the relationship that employees have with patients and their families needs to be considered in the nursing work of a hemodialysis service.

The socio-professional relationships were assessed in this study as satisfactory with regard to the risk of illness of nursing staff, unlike the evaluation of critical care nurses, in which it was considered moderate to critical. ${ }^{6}$ Although the overall assessment of socio-profefssional relationships in this study is more positive than evidenced in the aforementioned study, when separately analyzed, a poorer evaluation of the items, "lack integration in the work environment" and "communication between employees is unsatisfactory", was observed in nursing staff surveyed in this study. 
This result converged with the findings of a survey conducted with nurses from 17 dialysis centers in Turkey, which showed that $53.7 \%$ of respondents had problems with the staff, and of these, $44.5 \%$ had communication problems. ${ }^{12}$ Similarly, one study ${ }^{13}$ conducted in the same service found suffering at work, given the difficulties in interpersonal relationships among peers, which confirms that there is a possibility of illness pointed to by staff in the hemodialysis service.

Many problems arising from the interpersonal relationships within the healthcare team focus on the lack of proper communication in which there is not correct understanding of what is being communicated, the expected results, and the strategies to achieve this result. ${ }^{14}$

In this direction, one study ${ }^{15}$ indicated that lack of communication can cause feelings of worthlessness, professional devaluation, depression, emotional exhaustion, irritation and overburden on the nursing staff. On the other hand, promoting a working environment with good interpersonal relationships can impact positively on job satisfaction, enabling nursing staff to better confront daily adversities of hemodialysis work. ${ }^{16}$

The interpersonal relationships established between health professionals have been expressed in a unique way, according to the referential of life for each employee, and with patients. Thus, in relationships, each one leave his/her mark, expresses his way of acting, and influences the other either positively or negatively. ${ }^{14}$

Thus, there are skills that professional nurses need to develop, as the coordinator of the nursing staff, with the need to seek a theoretical basis and practical experience to manage interpersonal relationships. This professional must be able to identify, analyze and address work conflicts, collectively, in order to have the minimal interference on care. ${ }^{11}$

When assessing the risk of illness in nursing work within the hemodialysis service, from the socio-professional relationship standpoint, a more critical assessment was identified in staff who were less satisfied with their current remuneration and who suffered work-related accidents in the past year.

Research with nurses working in dialysis units in southern Brazil showed that low-paying jobs and a lack of recognition of the work were some of the situations considered stressful in nursing work in this work environment. Thus, satisfaction with the remuneration may be related to the appreciation and professional recognition of the staff, which tends to reflect positively on the socio-economic relationships established in the working environment, and consequently the health of staff members. ${ }^{17}$

With regard to increased risk of illness in the context of social and professional relationships between staff members who suffered occupational accidents, research ${ }^{18}$ points out that unexciting work activities, or those which are stressful and contentious, cause demotivation and constitute determining factors for non-adherence to the use of protective equipment, which further exposes staff members to occupational hazards and accidents.

The occurrence of occupational accidents involving exposure to biological material has been a factor suffered by the nursing staff, because, in addition to the emotional difficulties, the staff fear becoming ill, the repercussions for their family, work, among others, in addition to the embarrassment of having suffered the accident, and because he can be judged for that. ${ }^{19}$ These feelings may impair social and professional relationships and, consequently, produce a higher risk of illness related to work, which converges with the manifest critical evaluation by nursing staff who suffered work-related accidents in the past year.

The work contexts in which there are conflictual social and professional relationships require intervention, in order to encourage the establishment of a satisfactory working environment, which tends to have a positive impact on other spheres of the staff member's life, including her health condition.

Working conditions include the physical environment, chemicals, biologicals, hygiene, safety, anthropometric characteristics, the working conditions, materials and equipment. ${ }^{8}$ As in the intensive care nurse study, ${ }^{6}$ working conditions in the studied service were considered satisfactory. The results of these studies also converged for being unique reviews that described the reality of private health institutions.

Although this is not the reality of most of the country's health services, in the researched context, it is necessary to consider that if, on the one hand, satisfactory working conditions reverberate positively on work implementing, patient safety and job satisfaction; on the other, they may be related to higher costs for results and productivity, which can have a negative impact on staff members' health. 
Research in a public hospital of Minas Gerais reported that the lack of supplies and shortage of equipment associated with the huge demand of users caused stressful and conflictual situations in the nursing team, and, at times, disputes occurred between members about using or acquiring the materials required, in order to conduct their activities and provide safe patient care. ${ }^{11}$

In the researched context, "there is a lot of noise in the work environment" and "working conditions pose risks to the people's safety", aspects were considered critical by nursing staff. Noise exposure was also highlighted in a study on working conditions in the nursing units of a university hospital, ${ }^{19}$ and by nurses working in dialysis services in Turkey. ${ }^{20}$

As with the intensive care unit, the hemodialysis unit is a closed environment with unfavorable acoustics and more sensitivity to noise. ${ }^{6}$ In addition to this is the diversity of noise produced in hemodialysis rooms, especially dialysis equipment alarms, television, air conditioning, conversations between patients, and patient equipment sounds.

The effects of exposure to excessive noise in the work environment are not limited to hearing damage, but can cause increased fatigue and stress, sleep disorders and cardiovascular diseases. One of its negative effects is the fact that the noise overlaps safety warnins sounds and compromises communication between staff members, increasing the risk of accidents. ${ }^{21}$

In addition to the discomfort and harmful effect of noise to the staff the risk of excess noise in the researched work environment, which impairs the early identification of any problems with the dialysis equipment, which can jeopardize not only staffs' health, but also patient safety.

Evaluation of staffs of which working conditions pose risks to human health, converges with the findings of a study ${ }^{22}$ on dialysis units from Egypt, where half of nurses reported having had an accident with sharp devices last year, which refers to the high occupational exposure of nursing staffs in this sector.

For these reasons, poor working conditions in hospitals, especially in hemodialysis services, denote a serious situation of health risk to staff members, since such conditions increase risks inherent in nursing activities. Therefore, despite satisfactory assessment regarding the work conditions, the staff members themselves recognize that their activity in the hemodialysis service offers risks to health, which suggests the need for such aspects to be constantly evaluated and reconsidered in order to minimize the risk of health problems of staff members.

\section{CONCLUSION}

The researched work context is not entirely favorable to the health of the nursing staff, since the organization of work was considered critical. Socio-occupational relationships and work conditions in the hemodialysis service were assessed satisfactorily.

The staff members who were least satisfied with the current remuneration, and those who suffered occupational accidents in the last year, evaluated the social and professional relationships more negatively. Exposure to excessive noise, repetitive tasks, and evaluation by respondents that their work activity poses health risks to people also composed the working environment in the hemodialysis service.

Although WCAS-EACT is not a specific instrument for nursing staff, it demonstrated internal consistency when applied to this population. The use of the instrument proved useful, as it allowed the performance of a work context evaluation in hemodialysis service, which can be deepened with qualitative techniques and application of other instruments.

The need for training in nursing also addresses aspects related to staff members' health in teaching aspects. Nurses need to evaluate and intervene in the work context where they are integrated, mainly in promoting favorable conditions for worker health, and consequently safe, skilled nursing care.

The results of this study also represented advances in knowledge in the occupational health field, keeping in view the shortage of domestic production with this approach. The limitations include the size of the study population and the fact that the survey was conducted in a single service. Thus, additional research is suggested that addresses nursing work and staff members' health in hemodialysis services, with issues such as work accidents, socio-professional relationships, and defensive strategies.

\section{REFERENCES}

1. Dejours C. A loucura do trabalho: estudo de psicopatologia do trabalho. São Paulo (SP): CortezOboré; 2009. 
2. Jacques MG. O nexo causal em saúde/doença mental no trabalho: uma demanda para a psicologia. Psicol Soc [online]. 2007 [acesso 2014 Abr 11]; 19(spe):112-9. Disponível em: http://www.scielo. br/scielo.php? script $=$ sci_pdf\&pid $=$ S010271822007000400015\&lng=en\&nrm=iso\&tlng=pt

3. David HMSL, Mauro MYC, Silva VG, Pinheiro MAS, Silva FH. Organização do trabalho de enfermagem na atenção básica: uma questão para a saúde do trabalhador. Texto Contexto Enferm [online]. 2009 [acesso 2013 Out 18]; 18 (2):206-14. Disponível em: http://www.scielo.br/pdf/tce/v18n2/02.pdf

4. Silva MKD, Zeitoune RCG. Riscos ocupacionais em um setor de hemodiálise na perspectiva dos trabalhadores da equipe de enfermagem. Esc Anna Nery [online]. 2009 [acesso 2014 Jan. 02], 13(2):27986. Disponível em: http:/ /www.scielo.br/pdf/ean/ v13n2/v13n2a07.pdf

5. Ribeiro RP, Martins JT, Marziale MHP, Robazzi MLCC. O adoecer pelo trabalho na enfermagem: uma revisão integrativa. Rev Esc Enferm USP [online]. 2012 Abr [acesso 2013 Dez. 11]; 46(2):495504. Disponível em: http://www.scielo.br/pdf/ reeusp/v46n2/a31v46n2.pdf

6. Campos JF, David HSL. Work context assessment in intensive therapy units from the perspective of work psychodynamics. Rev Esc Enferm USP [online]. 2011 [cited 2013 Oct 18]; 45(2):363-8. Available from: http://www.scielo.br/pdf/reeusp/v45n2/ en_v45n2a08.pdf

7. Mendes AM. Da psicodinâmica à psicopatologia do trabalho. In: Mendes AM, organizadora. Psicodinâmica do trabalho: teoria, método e pesquisas. São Paulo (SP): Casa do Psicólogo; 2007. p. 29-48.

8. Mendes AM, Ferreira MC. Inventário de trabalho e riscos de adoecimento - ITRA: instrumento auxiliar de diagnóstico. In: Mendes AM, organizadora. Psicodinâmica do trabalho: teoria, método, pesquisas. São Paulo (SP): Casa do Psicólogo; 2007. p. 111-126.

9. Rossi EZ, Mendes AM. Stratégie de défense et anesthésie de la douleur dands l'étiologie des TMS. Travailler Revigny-sur-Ornain. 2009; 22(2):101-20.

10. Prestes FC, Beck CLC, Tavares JP, Silva RM, Cordenuzzi OCP, Burg G, et al. Percepção dos trabalhadores de enfermagem sobre a dinâmica do trabalho e os pacientes em um serviço de hemodiálise. Texto Contexto Enferm [online]. 2011 [acesso 2013 Out 18]; 20(1):25-32. Disponível em: http://www.scielo.br/pdf/tce/v20n1/03.pdf

11. Spagnol CA, Santiago GR, Campos BMO, Badaró MTM, Vieira JS, Silveira APO. Situações de conflito vivenciadas no contexto hospitalar: a visão dos técnicos e auxiliares de enfermagem. Rev Esc Enferm USP [online]. 2010 [acesso 2014 Jan 02]; 44(3):803-11. Disponível em: http://www.scielo.br/pdf/reeusp/ v44n3/36.pdf
12. Kapucu SS, Akkus Y, Akidemir N, karacan Y. The burnout and exhaustion levels of nurses working in haemodialysis units. J Ren Care. 2009; 25(3):134-40.

13. Prestes FC, Beck CLC, Silva RM, Tavares JP, Camponogara S, Burg G. Prazer-sofrimento dos trabalhadores de enfermagem de um serviço de hemodiálise. Rev Gaúcha Enferm [online]. 2010 [acesso 2013 Out 18]; 31(4):738-45. Disponível em: http://www.scielo.br/pdf/rgenf/v31n4/ a18v31n4.pdf

14. Cunha PJ, Zagonel IPS. The interpersonal relationships of care actions in the hospital technological environment. Acta Paul Enferm [online]. 2008 [cited 2013 Oct 18]; 21(3):412-9. Available from: http://www.scielo.br/pdf/ape/ v21n3/05.pdf

15. Minimel VA, Baptista PCP, Felli VEA. Psychic workloads and strain processes in nursing workers of Brazilian University Hospitals. Rev Latino-Am Enferm [online]. 2011 [cited 2013 Oct 18]; 19(2):3407. Available from: http://www.scielo.br/pdf/rlae/ v19n2/16.pdf

16. Hayes B, Bonnet A. Job satisfaction, stress and burnout associated with haemodialysis nursing: a review of literature. J Ren Care. 2010; 36(4):174-9.

17. Zonin M, Lautert L. Estresse e coping no cotidiano de trabalho de enfermeiros(as) de hemodiálise. In: Thomé EGR, Lautert L, organizadores. Enfermagem em diálise. Brasília (DF): ABEn, 2009. 226 p.

18. Neves HCC, Souza ACS, Medeiros M, Munari DB, Ribeiro LCM, Tipple AFV, et al. Segurança dos trabalhadores de enfermagem e fatores determinantes para adesão aos equipamentos de proteção individual. Rev Latino-Am Enferm [online]. 2011 [acesso 2014 Jan. 02]; 19(2):354-61. Available from: http://www.scielo.br/pdf/rlae/ v19n2/pt_18.pdf

19. Secco IAO, Robazzi MLCC, Souza FEA, Shimizu DS. Cargas psíquicas de trabalho e desgaste dos trabalhadores de enfermagem de hospital de ensino do Paraná, Brasil. SMAD, Rev Eletrôn Saúde Mental Álcool Drog [online]. 2010 [acesso 2014 Abr 11]; 6(1):10-17. Disponível em: http://pepsic.bvsalud. $\mathrm{org} / \mathrm{pdf} / \mathrm{smad} / \mathrm{v} 6 \mathrm{n} 1 / 16 . \mathrm{pdf}$

20. Cürcani M, Tan M. Occupational risk factors and health problems faced by nurses that working dialysis unit and nephrology service. TAF Prev Med Bull [online]. 2009 [cited 2014 Apr 11]; 8(4):33944. Available from: http://www.scopemed.org/ fulltextpdf.php?mno=769

21. União Europeia [online]. Agência Europeia para a saúde e segurança no trabalho. Novos riscos emergentes para a saúde e segurança no trabalho. Luxemburgo: Serviço das Publicações Oficiais das Comunidades Europeias; 2009 [acesso 2014 Abr 11]; Disponível em: http://apespe.onlinemarketing4u. net/admin/documents/userid7_23_02_2010_ 
Novos \%20riscos\%20emergentes \%20para \%20a \%20

Seguran \% C3\% A7a \% 20e\% 20Sa \% C3\%BAde \% 20 no\%20Trabalho.pdf

22. Kabbash I, El-Sayed NM, Al-Nawawy AN, Abou
SMS, Al Deek B, Hassan NM. Risk perception and precautions taken by health care workers for HIV infection in hemodialysis units in Egypt. East Mediterr Health J. 2007 Mar-Apr; 13(2):392-407. 